tion to textiles. Dr. C. H. Spiers, who is himself a chemist, read a paper entitled "Some Physical Problems of Leather Manufacture" in an effort to show how tremendously wide is the scope for the application of physics in relation to tannery problems ; his paper is printed in full in the Leather Trades' Review for October 4.

\section{Archæological Finds in the Crimea}

A JOINT expedition of the University Museum, Philadelphia, and the Leningrad Academy for the History of Material Culture has been engaged in the exploration of an ancient fortress site at EsskiKermen in the Crimea under the direction of Prof. P. L. Schmidt, representing the Leningrad Academy. According to a communication issued by the S.C.R., a large amount of archæological material obtained from interments, consisting of pottery, bones and ornaments, has already reached Leningrad, where it awaits examination. In the slopes of the plateau on which the fortress stands, thirty-three catacomb burials were discovered. These date from the fifth to seventh centuries A.D. Inside the fortress were a number of communal burial chambers, cut from the solid rock. These contained human skeletal remains, which had evidently been deposited there after having first been interred elsewhere. They closely resemble burial chambers discovered at Mengap-Kale. These remains are believed to belong to the people previously known only from the 'dolmen' burials. It is hoped to establish their cultural affinities and chronological relations by the present excavations. Four large dolmens and eight cist burials were also examined and yielded three unbroken skulls, the first to be found in this region. Archæological investig. ation in the Crimea has demonstrated a succession of five occupations, of which the best known is that of the bronze age Scyths, whose art, characterised by the free use of animal motives, is known from widely distributed burials, and extended as far as China. It is anticipated that the present excavations will at least establish certain fixed points in the chronology of the at present obscure prehistory of the Crimea.

\section{Amani Agricultural Research Station}

THE fifth annual report (1932-1933) of the Amani Agricultural Research Station has been issued by the Colonial Office (London: H.M. Stationery Office. 1s. net), and in a covering letter attention is directed to the fact that this is "the first report since the Station has really got going and stood upon its own feet". Definite advances have been made along many lines of investigation, and although a programme of long-range research has been followed, some important results capable of immediate application have been obtained. An intensive study of the root system of coffee has revealed the fact that a close correlation exists between root distribution and the acidity gradient of the soil profile. Where the reaction is approximately neutral, a uniform dispersal of roots is found throughout the soil, but should a mildly acid or neutral layer overlie an acid subsoil, the roots will be restricted to the upper layer. This behaviour suggests an explanation of many long-standing problems with regard to coffee-growing. The sisal industry has hitherto been chiefly devoted to the manufacture of binder twine, but an extension of the uses of the fibre is now taking place which affords an opportunity to develop special lines to serve particular purposes. This has necessitated a systematic examination of sisal seedlings and seedling hybrids, in the course of which a hitherto undescribed species has been discovered. The latter shows marked superiority to sisal, the rate of growth being greater, and its fibre being both softer, finer, and with a greater tensile strength. There seems no reason to doubt that this species will either replace sisal to a considerable extent, or supplement it and facilitate the extension of its present uses. An account of the Amani Agricultural Research Station was given by its director, Mr. William Nowell, before the Royal Society of Arts on October 24.

\section{Broadcast Reception and Electrical Interference}

THE Institution of Electrical Engineers has recently set up a Committee to consider the various problems involved in interference with the reception of broadcasting caused by electrical machinery and apparatus. This Committee, which is representative of the various interests involved in the matter, has been considering the means which might be adopted to render future plant and appliances non-interfering, in addition to the possible methods for dealing with the interference apart from suppression at the source. With the assistance of four sub-committees, the disturbance due to such items as lifts, trolley omnibuses, domestic appliances and other apparatus have been investigated; and it would appear that in many cases devices for the suppression of the interference could be incorporated in future designs at a reasonable cost. In order to facilitate progress in this direction, it has been decided to seek the co-operation of the manufacturers and other interests affected; while the possibility of international action on the question of electrical equipment embodying suppression devices will receive consideration by a British National Committee to be set up for the purpose. Further investigation appears to be necessary on some of the larger items of plant, and quantitative tests on these are being carried out by the British Electrical and Allied Industries Research Association.

\section{Cinematograph Films for Teaching}

Reference was made in NAture of December 17, 1932 , p. 921 , to the cinematograph films of cyclic phenomena produced by Messrs. Dance-Kaufmann, 18 Upper Stanhope Street, Liverpool, 8. We have now received a new list of films available. Before referring to the subjects dealt with, some features of these films may be emphasised. As Messrs. DanceKaufmann point out, their films are definitely for teaching purposes, preferably in the class-room, and not for entertainment. All are safety films and they are supplied for $35 \mathrm{~mm}$., $16 \mathrm{~mm}$. and $9.5 \mathrm{~mm}$. projectors at one uniform price. The only adaptation 
to standard projectors required is a loop absorber, for all the films are in the form of loops so that the phenomena illustrated can be repeated indefinitely. The subjects included in the present list include the production of mathematical curves, combination of harmonic motions (including harmonics), wave motion, light, electrostatics and elementary electricity, theory of alternating currents and of the induction motor, electric valves, mechanisms, heat engines, pumps, etc. Most of the films are produced from cartoons, but the engineering subjects include several films in 'half-tone' of models or full-scale apparatus. Messrs. Dance-Kaufmann are prepared to advise on suitable apparatus for showing their films.

\section{Science and Wheat-Growing}

The issue of the Journal of the Society of Chemical Industry for August 4 contains an informative article, entitled "How Science can help to improve the Nation's Food Supply-Wheat", by Dr. E. A. Fischer, director of the Research Association of British Flour-Millers. Until comparatively recently, the main object of the wheat grower was to obtain a good yield per acre, the milling and baking qualities of the product being disregarded. Dr. Fisher outlines the history of the wheat-growing and milling indus tries during the past sixty years and shows how it explains the apathy and ignorance concerning wheat quality formerly prevalent in Great Britain. The first important step in enhancing the quality of English wheats was Biffen's achievement in producing the Yeoman wheats. These are, however, not suitable for all soils or all districts, and much further improvement is necessary if the output of home. grown wheat is to be increased materially. The directions in which such improvement may be accomplished may be summarised as follows : development and extended use of wheat-drying machinery on the farm; development of new varieties of wheat of higher protein content and better gluten quality, and suitable for all wheat-growing districts ; development in the mills of flour-conditioning processes by which the baking characters of flours may be improved. The fate of the English wheat-grower is closely linked to that of the country miller, and his aim should be the production of wheats which may be ground and consumed where grown, with little or no admixed foreign wheat, heavy transport charges being thus saved.

\section{Science for Citizenship}

IN connexion with the article in NATURE of October 14 , p. 581, under this title, a correspondent recalls an opinion on the general subject expressed by Sir Horace Lamb, in 1925, when he occupied the presidential chair at the meeting of the British Association at Southampton. Sir Horace said, "The habit of sober and accurate analysis which scientific pursuits tend to promote is not always favourable to social and economic theories, which rest mainly on an emotional, if very national basis. There is, I think, a certain dumb hostility, which, without venturing on open attack, looks coldly on scientific work, except so far as it is directed to purposes of obvious and immediate practical utility".

\section{Announcements}

Prof. Sydney Chapman, professor of mathematics in the Imperial College of Science, will deliver a lecture on "The Sun's Magnetism" before the Institution of Professional Civil Servants at the Royal Society of Arts, John Street, Adelphi, London, W.C.2, on November 24 at 5.30 p.m. The lecture will be open to the public.

Mr. C. T. P. ULM, together with his assistant pilots, Messrs. G. U. Allen and P. G. Taylor, landed in Derby, Western Australia on October 20 at 12.15 a.m. (local time), thus completing the flight from England in 6 days 17 hours and 56 minutes. This beats the record set up by Sir Charles Kingsford Smith in his recent solo flight by 10 hours 54 minutes. The machine used was an Avro Ten, fitted with three Wright Whirlwind engines.

The Ramsay Memorial Fellowship Trustees have made the following awards of new fellowships for the year 1933-34 : Dr. A. G. Winn, a British fellowship of $£ 300$, tenable for two years, at University College, London; Dr. N. W. H. Addink, a Netherland fellowship of $£ 300$, at the University of Cambridge; Dr. J. Smittenberg, a Netherland fellowship of $£ 300$, at the University of Bristol. The Trustees have renewed the following fellowships for the year 1933-34: Dr. J. M. Albareda (Spanish fellow), Rothamsted Experimental Station, Harpenden, Herts; Dr. Walter Cawood (British fellow), University of Leeds ; Dr. C. Kawassiades (Greek fellow), University College, London; Dr. Mario Liguori (Italian fellow), University of Oxford ; Dr. John MacArthur (Glasgow fellow), Royal Institution, London.

Aт the annual statutory meeting of the Royal Society of Edinburgh held on October 23, the following Council was elected :--President: Sir E. A Sharpey-Schafer; Vice-Presidents : Dr. J. B. Clark, Prof. James Ritchie, Sir Thomas H. Holland, the Hon. Lord Sands, Prof. C. G. Darwin, Prof. R. A. Sampson; General Secretary : Prof. J. H. Ashworth ; Secretaries to Ordinary Meetings: Prof. F. A. E. Crew and Prof. James P. Kendall; Treasurer: Dr. James Watt ; Curator of Library and Museum : Prof. D'Arcy W. Thompson; Councillors: Prof. P. T. Herring, Prof. T. M. MacRobert, Prof. Godfrey H. Thomson, Dr. Malcolm Wilson, Prof. E. B. Bailey, Prof. J. C. Brash, Prof. A. J. Clark, Prof. A. G. Ogilvie, Prof. E. M. Wedderburn, Lieut.-Col. A. G. M'Kendrick, Prof. James MacKinnon and Prof. W. Peddie.

Applications are invited for the following appointments, on or before the dates mentioned :-A lecturer in biology at the Leicester College of TechnologyThe Director of Education (Oct. 30). A professor of education, and a professor of dental science, in the University of Melbourne-The Agent-General for Victoria, Melbourne Place, Strand, London, W.C,2, 